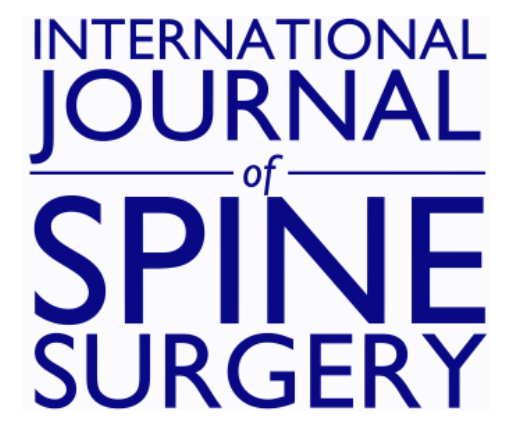

\title{
Effect of perioperative steroids on dysphagia after anterior cervical spine surgery: A systematic review
}

Abidemi S. Adenikinju, Sameer H. Halani, Rima S. Rindler, Matthew F. Gary, Keith W. Michael and Faiz U. Ahmad

Int J Spine Surg 2017, 11 (2)

doi: https://doi.org/10.14444/4009

http://ijssurgery.com/content/11/2/9

This information is current as of April 25, 2023.

Email Alerts Receive free email-alerts when new articles cite this article. Sign up at:

http://ijssurgery.com/alerts

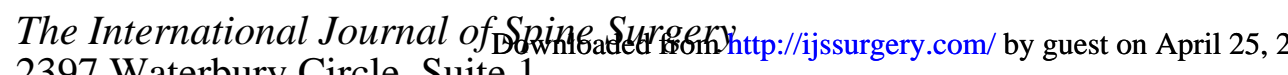
2397 Waterbury Circle, Suite 1,

Aurora, IL 60504, Phone: +1-630-375-1432 


\section{Effect of perioperative steroids on dysphagia after anterior cervical spine surgery: A systematic review}

Abidemi S. Adenikinju, BA, ${ }^{1}$ Sameer H. Halani, MS, ${ }^{1}$ Rima S. Rindler MD, ${ }^{1}$ Matthew F. Gary MD, ${ }^{1}$ Keith W. Michael MD, ${ }^{2}$ Faiz U. Ahmad MD, MCh ${ }^{1}$

${ }^{1}$ Department of Neurosurgery, Emory University School of Medicine, Atlanta, GA, USA, ${ }^{2}$ Department of Orthopaedic Surgery, Emory University School of Medicine, Atlanta, GA, USA

\section{Abstract}

\section{Background}

Dysphagia following anterior cervical spine surgery is common. Steroids potentially reduce post-operative inflammation that leads to dysphagia; however, the efficacy, optimal dose and route of steroid administration have not been fully elucidated.

\section{Objective}

The purpose of this systematic review is to evaluate the effect of peri-operative steroids on the incidence and severity of dysphagia following anterior cervical spine surgery.

\section{Methods}

A PubMed search adherent to the Preferred Reporting Items for Systematic Reviews and Meta-Analyses guidelines was performed to include clinical studies reporting use of steroids in adult patients following anterior cervical spine surgery. Data regarding steroid dose, route and timing of administration were abstracted. Incidence and severity of post-operative dysphagia were pooled across studies.

Results

Seven of 72 screened articles met inclusion criteria for a total of 246,298 patients that received steroids. Patients that received systemic and local steroids had significant reductions in rate and severity of dysphagia postoperatively. Reduction of dysphagia severity was more pronounced in patients undergoing multilevel procedures in both groups. There was no difference in infectious complications among patients that received steroids compared with controls. There was no difference in fusion rates at long-term follow-up.

\section{Conclusions and Clinical Relevance}

Steroids may reduce dysphagia after anterior cervical spinal procedures in the early post-operative period without increasing complications. This may be especially beneficial in patients undergoing multilevel procedures. Future studies should further define the optimal dose and route of steroid administration, and the specific contraindications for use.

\section{Introduction}

Rationale

The anterior approach is commonly utilized in surgical management of cervical spine pathology. Though it is generally considered safe, there have been reports of various complications. ${ }^{1,2}$ One such complication is postoperative dysphagia. Dysphagia following anterior cervical spine surgery is a significant postoperative complaint, with a reported incidence of up to Downloaded from http://ijssurgery.com/ by guest on April 25, 2023
$79 \%{ }^{3.5}$ Symptoms primarily occur during the early postoperative period, decreasing significantly by 6 months post-op and ultimately plateauing at 1 year in most patients. ${ }^{3,4}$ Dysphagia persisting past 1 year has a prevalence of $15.2 \%{ }^{5}$ The etiology of postoperative dysphagia is multifactorial. Contributing factors include prevertebral soft tissue swelling, vocal cord paresis, ${ }^{4,67}$ scar tissue formation, hardware complication and cervical graft material. ${ }^{1,4,8}$ Risk factors that have been identified include multilevel fusion and fe- 
male gender, ${ }^{3,4,910}$ revision surgery, ${ }^{5}$ and plate prominence. ${ }^{2,11}$

Given that dysphagia is a common complication of anterior cervical spine surgery, numerous techniques have been investigated to decrease its incidence, decreased plate prominence and cuff pressure are just a few. ${ }^{2,4,10,11}$ One therapeutic intervention that shows promise is the use of perioperative steroids..$^{12-18}$ By reducing the inflammatory response, steroids should decrease dysphagia as well as pain in the postoperative period. ${ }^{16}$ The use of steroids has resulted in decreased dysphagia incidence and severity as well as airway edema, in some studies ${ }^{12,1518}$; however, in other studies the effect of steroids has been equivocal. ${ }^{13} \mathrm{In}$ addition to these inconsistent results with dysphagia, there is concern about the adverse effects of steroids, such as delayed time to fusion and increased infection rates. ${ }^{1,19}$ The use of both systemic and local steroids has been reported in previous studies..$^{12-18}$ The main justification of local steroids over systemic has been the presumed lower rate of systemic complications with local use. ${ }^{16}$ Efficacy between the two methods has not yet been compared.

Though the use of perioperative steroids in preventing dysphagia after anterior cervical spine surgery has been examined in various studies, a consensus regarding efficacy has yet to be reached.

\section{Objectives}

The purpose of this review was to evaluate the efficacy of perioperative steroids in reducing dysphagia incidence and severity after anterior cervical spine procedures by performing a systematic review of the literature.

\section{Methods}

\section{Study Selection}

A literature review of PubMed was performed according to Preferred Reporting Items for Systematic Reviews and Meta-Analyses (PRISMA) guidelines. ${ }^{20}$ The following search terms were screened for inclusion: ["steroids"] AND ["anterior cervical fusion" OR "ACDF"] AND ["dysphagia" OR "odynophagia"]. Clinical articles written in the English language and published between 1990 and 2016 were screened for inclusion. Inclusion criteria were as follows (1) articles describing anterior cervical spine surgery in adult humans; (2) use of pre-, intra-, or post-operative steroids; (3) assessment of postoperative dysphagia or odynophagia. Duplicate articles, reviews, letters to the editors, and commentaries were excluded. The literature searches were independently performed by two authors (AA and $\mathrm{SH}$ ); disagreements were resolved by consensus. A thorough bibliographic search of screened articles was also performed for additional qualifying articles. The last search was performed on January 31, 2016.

\section{Data Extraction \& Quality Assessment}

Where available, the following data were extracted from each included study: sample size; basic demographics; type and dose of steroid used; frequency of single versus multilevel procedures; length of hospital stay; time to follow-up; incidence and severity of post-operative dysphagia; radiographic measures of prevertebral soft tissue swelling; postoperative complications; and time to fusion. Calculations for steroid dose equivalents were completed using standard conversions as described in the literature $(20 \mathrm{mg}$ dexamethasone: $106.67 \mathrm{mg}$ methylprednisolone, $106.67 \mathrm{mg}$ triamcinolone). ${ }^{2123}$ For non-randomized cohort and case-control studies, the Newcastle-Ottawa Scale was used to assess quality and risk of bias. This is a 9-point scale assessing cohort selection, comparability, and outcome or exposure, with a higher score indicating higher quality. ${ }^{24}$

\section{Primary \& Secondary Outcomes}

The primary study outcomes were incidence and severity of post-operative dysphagia and/or odynophagia after anterior cervical spine procedures. Studies investigating the severity of dysphagia used various standardized scoring systems, which are summarized in Table 1. Secondary outcomes included severity of prevertebral soft tissue swelling, time to fusion, length of hospital stay, post-operative pain, and other complication rates.

\section{Statistical Analysis}

It is noted that not all studies provided data or information on each subset of patients; therefore comparative analysis is limited by to the nature of the source data. Data for all patients was reported when avail- 
able in the literature. Statistical analysis was not conducted for this review because comparative analyses could not be performed.

\section{Results}

\section{Study Selection}

Seventy-two articles were identified from the initial literature search. Fifty-one non-duplicates underwent abstract and title review for applicability and in- clusion. Nine underwent full-text review. Two articles were excluded due to lack of sufficient outcome data for post-operative dysphagia/odynophagia. The remaining 7 articles met inclusion criteria. Five articles were prospective randomized controlled trials ${ }^{12-16}$; and two were retrospective case-control studies. ${ }^{1718}$ The results of the literature search are summarized in the PRISMA flow diagram (Figure 1).

\section{Study Characteristics}

The randomized controlled trials $(n=5)$ are graded as

Table 1. Summary of assessments used to measure dysphagia and highlights of individual study outcomes.

\begin{tabular}{|c|c|c|c|c|}
\hline $\begin{array}{l}\text { Study, } \\
\text { year }\end{array}$ & $\begin{array}{l}\text { Dysphagia } \\
\text { Severity } \\
\text { Assessment }\end{array}$ & Assessment Description & Results & Conclusion \\
\hline \multicolumn{5}{|c|}{ SYSTEMIC STEROIDS } \\
\hline $\begin{array}{l}\text { Pedram, } \\
2003\end{array}$ & $\mathrm{~N} / \mathrm{a}$ & $\begin{array}{l}\text { Patient subjectively described swallowing difficulty } \\
\text { without standardized scale }\end{array}$ & $\begin{array}{l}\text { Dysphagia or odynophagia reported } \\
24-36 \mathrm{~h} \text { post-operatively in } 56(71.79 \%) \\
\text { steroid-treated patients compared to } 130 \\
(82.28 \%) \text { control patients. }\end{array}$ & $\begin{array}{l}\text { Perioperative systemic steroids } \\
\text { reduce incidence of post-operative } \\
\text { swallowing impairment in the early } \\
\text { post-operative period. }\end{array}$ \\
\hline Nam, 2013 & $\begin{array}{l}\text { Visual } \\
\text { analogue } \\
\text { scale (VAS) } \\
\text { for } \\
\text { dysphagia }\end{array}$ & $\begin{array}{l}\text { 10-point scale based on patient self-report of swallowing } \\
\text { difficulty }(0=\text { no difficulty swallowing, } 10=\text { worst } \\
\text { difficulty swallowing). }\end{array}$ & $\begin{array}{l}\text { No statistically significant differences in } \\
\text { mean VAS scores between high dose } \\
\text { steroids, low dose steroids, and control } \\
\text { groups noted during the first } 5 \text { post-op } \\
\text { days. }\end{array}$ & $\begin{array}{l}\text { Perioperative systemic steroids do } \\
\text { not affect severity of post-operative } \\
\text { swallowing impairment in the early } \\
\text { post-operative period. }\end{array}$ \\
\hline Song, 2014 & $\begin{array}{l}\text { Bazaz } \\
\text { Dysphagia } \\
\text { Score }\end{array}$ & $\begin{array}{l}\text { Dysphagia described as absent, mild, moderate, severe } \\
\text { based on patient report. }\end{array}$ & $\begin{array}{l}\text { Steroid group had lower Bazaz ratings } \\
\text { compared to control group during POD } \\
2-5 \text { ( } p<0.05 \text { each day). }\end{array}$ & $\begin{array}{l}\text { Perioperative systemic steroids } \\
\text { improve post-operative severity in } \\
\text { the early post-operative period. }\end{array}$ \\
\hline $\begin{array}{l}\text { Jeyamohan, } \\
2015\end{array}$ & $\begin{array}{l}\text { Functional } \\
\text { Outcome } \\
\text { Swallowing } \\
\text { Scale } \\
\text { (FOSS) }\end{array}$ & $\begin{array}{l}\text { Score } 0-5 \text { based on patient report of swallowing function, } \\
\text { frequency of associated symptoms, and need for non-oral } \\
\text { feeding }\end{array}$ & $\begin{array}{l}\text { Steroid group lower mean FOSS score at } \\
\text { 1-month follow-up compared to control } \\
\text { group }(0.064 \text { vs. } 0.66, \mathrm{p}=0.027) \text {; this } \\
\text { difference disappeared after } 1 \text { month. }\end{array}$ & $\begin{array}{l}\text { Perioperative systemic steroids } \\
\text { improve post-operative dysphagia } \\
\text { severity in the early post-operative } \\
\text { period, which subsides in the } \\
\text { long-term. }\end{array}$ \\
\hline \multicolumn{5}{|c|}{ LOCAL STEROIDS } \\
\hline Lee, 2011 & $\begin{array}{l}\text { Visual } \\
\text { analogue } \\
\text { scale (VAS) } \\
\text { for } \\
\text { odynophagia }\end{array}$ & $\begin{array}{l}\text { 10-point scale based on patient self-report of pain with } \\
\text { swallowing }(0=\text { no pain; } 10=\text { worst pain }) .\end{array}$ & $\begin{array}{l}\text { Steroid group exhibited statistically } \\
\text { significant lower mean VAS } \\
\text { odynophagia scores immediately and at } \\
\text { 2-weeks post-operation. }\end{array}$ & $\begin{array}{l}\text { Perioperative local steroids reduce } \\
\text { post-operative dysphagia in the } \\
\text { early post-operative period. }\end{array}$ \\
\hline $\begin{array}{l}\text { Cancienne, } \\
2015\end{array}$ & $\mathrm{~N} / \mathrm{a}$ & $\begin{array}{l}\text { Patient subjectively described swallowing difficulty } \\
\text { without normalized scale }\end{array}$ & $\begin{array}{l}9 \% \text { of steroid group vs. } 14.6 \% \text { of control } \\
\text { group experienced dysphagia within } 90 \\
\text { days of fusions with } 3 \text { or more levels } \\
(p=0.005)\end{array}$ & $\begin{array}{l}\text { Perioperative local steroids reduce } \\
\text { incidence of post-operative } \\
\text { dysphagia in patients undergoing } \\
\text { anterior cervical spinal fusion of } 3 \\
\text { or more levels. }\end{array}$ \\
\hline \multirow{2}{*}{$\begin{array}{l}\text { Koreckij, } \\
2016\end{array}$} & $\begin{array}{l}\text { Bazaz } \\
\text { Dysphagia } \\
\text { Scale }\end{array}$ & $\begin{array}{l}\text { Dysphagia described as absent, mild, moderate, severe } \\
\text { based on patient report. }\end{array}$ & $\begin{array}{l}\text { Steroid group had fewer patients with } \\
\text { severe dysphagia at } 6 \text { weeks post-op } \\
(14.3 \% \text { vs. } 40.9 \%, p=0.008 .) \text { and } 3 \text { month } \\
(0 \% \text { vs. } 23.9 \%, p=0.022) \text { compared to } \\
\text { controls. }\end{array}$ & $\begin{array}{l}\text { Perioperative local steroids improve } \\
\text { post-operative dysphagia severity } \\
\text { beyond the early post-operative } \\
\text { period. }\end{array}$ \\
\hline & $\begin{array}{l}\text { EAT-10: A } \\
\text { swallowing } \\
\text { screening } \\
\text { tool }\end{array}$ & $\begin{array}{l}10 \text { item questionnaire evaluating swallowing and } \\
\text { associated psychosocial issues. Each item scored } 0-4(0=\text { no } \\
\text { problem, } 4=\text { severe problem). Total score ranges from } 0-40 \text {. } \\
\text { Total score of } 3 \text { or higher is abnormal (indicative of } \\
\text { dysphagia). }\end{array}$ & $\begin{array}{l}\text { Steroid group had fewer patients with } \\
\text { abnormal EAT- } 10 \text { scores at } 3 \text { months } \\
\text { post-op in comparison to control group } \\
(18.2 \% \text { vs. } 57.1 \% \text {; }=0.012) \text {. }\end{array}$ & $\begin{array}{l}\text { Perioperative local steroids reduce } \\
\text { incidence of dysphagia in the late } \\
\text { post-operative period. }\end{array}$ \\
\hline
\end{tabular}

POD: post-operative day. 


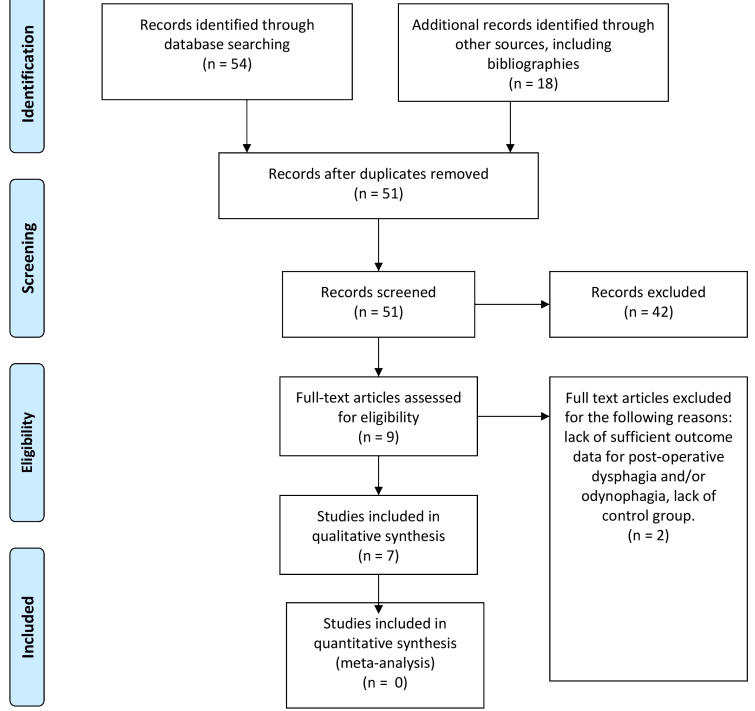

Fig. 1. PRISMA flow diagram for systematic reviews. level of evidence $1^{12 \cdot 16}$; the retrospective studies $(n=2)$ are graded as level of evidence $3 .^{17,18,25}$ Dysphagia was measured using a number of different modalities, which are summarized in Table 1.

\section{Patient Demographics}

A total of 246,298 patients were included across all studies; 194 patients received systemic steroids while 2,139 received local steroids; 243,965 subjects served as controls and received no intervention. Indication for initial anterior cervical spine surgery included: cervical radiculopathy, myelopathy, spondylosis, canal stenosis, disc herniation, and trauma. Dysphagia was measured post-operatively from immediately post-op to 24 months post-op. 52.94 percent $(130,390$ out of 246,298$)$ of patients were female. $\mathrm{Pa}$ tient and outcomes data are reported in Table $1 \&$ Table 2 . 
Table 2. Summary of patient and study demographics of patients receiving steroids after anterior cervical spine surgery.

\begin{tabular}{|c|c|c|c|c|c|c|c|c|c|c|c|c|c|c|c|c|}
\hline \multirow{2}{*}{$\begin{array}{l}\text { Author, } \\
\text { Year }\end{array}$} & \multirow[b]{2}{*}{ Design } & \multirow{2}{*}{$\begin{array}{l}\text { Total } \\
\text { number } \\
\text { of } \\
\text { patients } \\
\text { included }\end{array}$} & \multirow{2}{*}{$\begin{array}{l}\text { Number } \\
\text { of } \\
\text { operative } \\
\text { levels }\end{array}$} & \multirow{2}{*}{$\begin{array}{l}\text { Number of } \\
\text { multilevel } \\
\text { surgeries } \\
\text { included, } n \\
(\%)\end{array}$} & \multirow{2}{*}{$\begin{array}{l}\text { Major } \\
\text { indications for } \\
\text { initial anterior } \\
\text { cervical spinal } \\
\text { surgery }\end{array}$} & \multirow{2}{*}{$\begin{array}{l}\text { Follow-up } \\
\text { intervals }\end{array}$} & \multicolumn{4}{|c|}{ Demographics of Control Patients } & \multicolumn{4}{|c|}{ Demographics of Intervention Patients } & \multirow[b]{2}{*}{$\begin{array}{l}\text { Steroid } \\
\text { Dose } \\
\text { Frequency }\end{array}$} & \multirow[b]{2}{*}{$\begin{array}{l}\text { Steroid } \\
\text { Dose } \\
\text { Equivalent" }\end{array}$} \\
\hline & & & & & & & $\begin{array}{l}\text { Total } \\
\text { Patients }\end{array}$ & $\begin{array}{l}\text { Mean } \\
\text { Age (in } \\
\text { years) +/- } \\
\text { SD }\end{array}$ & $\begin{array}{l}\% \\
\text { Male }\end{array}$ & $\begin{array}{l}\text { Control } \\
\text { administered }\end{array}$ & $\begin{array}{l}\text { Total } \\
\text { patients }\end{array}$ & $\begin{array}{l}\text { Mean Age } \\
\text { +/- SD }\end{array}$ & $\begin{array}{l}\% \\
\text { Male }\end{array}$ & $\begin{array}{l}\text { Intervention } \\
\text { administered }\end{array}$ & & \\
\hline & \multicolumn{16}{|c|}{ SYSTEMIC STEROIDS } \\
\hline $\begin{array}{l}\text { Pedram, } \\
2003\end{array}$ & RCT & 236 & $1-5$ & $66(28)$ & $\begin{array}{l}\text { Cervical canal } \\
\text { stenosis, herniated } \\
\text { disc, trauma }\end{array}$ & 24-36h PO & 158 & $\begin{array}{l}47+/-15.3 \\
\text { (range: } \\
15-88 \text { ) }\end{array}$ & $\mathrm{n} / \mathrm{a}$ & N/A & 78 & $\begin{array}{l}47+/-12.3 \\
\text { (range: } \\
17-83 \text { ) }\end{array}$ & $\mathrm{n} / \mathrm{a}$ & $\begin{array}{l}\text { IV } \\
\text { Methylprednisolone }\end{array}$ & $\begin{array}{l}0 \mathrm{~h}, 12 \mathrm{~h} \\
24 \mathrm{~h}\end{array}$ & $0.19 \mathrm{mg} / \mathrm{kg}$ \\
\hline Nam, 2013 & RCT & 62 & 1 & $0(0)$ & $\begin{array}{l}\text { Cervical } \\
\text { radiculopathy }\end{array}$ & $\begin{array}{l}\text { Daily POD } \\
0-5\end{array}$ & 22 & 48.8 & 80 & NS & $\begin{array}{l}\text { High } \\
\text { dose: } 20 \\
\text { Low } \\
\text { dose: } 20\end{array}$ & $\begin{array}{l}\text { High dose: } \\
46.9+/-8.6 \\
\text { Low dose: } \\
45.6+/-7.3\end{array}$ & $\begin{array}{l}\text { High } \\
\text { dose: } \\
55 \\
\text { Low } \\
\text { dose: } \\
70\end{array}$ & IV Dexamethasone & $\begin{array}{l}\text { 0h, 24h, } \\
48 \mathrm{~h}\end{array}$ & $\begin{array}{l}\text { High dose: } \\
\text { 20/10/10mg } \\
\text { Low dose: } \\
\text { 10/5/5mg }\end{array}$ \\
\hline Song, 2014 & RCT & 40 & $>3$ & $40(100)$ & $\begin{array}{l}\text { Cervical } \\
\text { radiculopathy, } \\
\text { myelopathy }\end{array}$ & $\begin{array}{l}\text { Daily POD } \\
\text { 1-discharge }\end{array}$ & 20 & $\begin{array}{l}\text { 57.3+/-11 } \\
\text { (range: } \\
29-77)\end{array}$ & 80 & N/A & 20 & $\begin{array}{l}59.9+/-10.3 \\
\text { (range: } \\
42-47 \text { ) }\end{array}$ & 70 & $\begin{array}{l}\text { IV } \\
\text { Methylprednisolone }\end{array}$ & $\begin{array}{l}0 \mathrm{~h}, 6 \mathrm{~h}, \\
12 \mathrm{~h}, 18 \mathrm{~h}, \\
24 \mathrm{~h}\end{array}$ & $46.88 \mathrm{mg}$ \\
\hline \multirow[t]{2}{*}{$\begin{array}{l}\text { Jeyamohan, } \\
2015\end{array}$} & RCT & 112 & $\geq 2$ & $112(100)$ & $\begin{array}{l}\text { Cervical } \\
\text { spondylosis }\end{array}$ & $\begin{array}{l}1 \mathrm{mo}, 3 \mathrm{mo}, \\
6 \mathrm{mo}, \\
12 \mathrm{mo} \\
24 \mathrm{mo}\end{array}$ & 56 & 55 & 48.22 & NS & 56 & 54 & 58.93 & IV dexamethasone & $\begin{array}{l}\text { IO, } 6 \mathrm{~h}, \\
12 \mathrm{~h}, 18 \mathrm{~h}, \\
24 \mathrm{~h}\end{array}$ & $\begin{array}{l}0.20 \mathrm{mg} / \mathrm{kg} \\
\mathrm{IO}, 0.06 \mathrm{mg} / \\
\mathrm{kg} \mathrm{PO}\end{array}$ \\
\hline & \multicolumn{16}{|c|}{ LOCAL STEROIDS } \\
\hline Lee, 2011 & RCT & 50 & $1-2$ & $21(42)$ & $\begin{array}{l}\text { Cervical } \\
\text { radiculopathy, } \\
\text { myelopathy }\end{array}$ & $\begin{array}{l}\text { POD } 0,2, \\
4,2 \mathrm{wk}\end{array}$ & 25 & 50.9 & 56 & N/A & 25 & 54.3 & 72 & RP triamcinolone & IO & $7.50 \mathrm{mg}$ \\
\hline $\begin{array}{l}\text { Cancienne, } \\
2015\end{array}$ & $\begin{array}{l}\text { Retrospective } \\
\text { case control }\end{array}$ & 245754 & $\begin{array}{l}\text { Short } \\
\text { surgery: } \\
1-2 \\
\text { Long } \\
\text { surgery: } \\
\geq 3\end{array}$ & $\mathrm{n} / \mathrm{a}$ & $\mathrm{n} / \mathrm{a}$ & $\begin{array}{l}\text { Within } \\
\text { POD 0-90 }\end{array}$ & 243,662 & $\mathrm{n} / \mathrm{a}$ & $\begin{array}{l}\text { Short } \\
\text { surgery: } \\
47 \\
\text { Long } \\
\text { surgery: } \\
47.5\end{array}$ & N/A & 2092 & $\mathrm{n} / \mathrm{a}$ & $\begin{array}{l}\text { Short } \\
\text { surgery: } \\
40.3 \\
\text { Long } \\
\text { surgery: } \\
42.1\end{array}$ & $\begin{array}{l}\text { RP } \\
\text { Triamcinolone or } \\
\text { methylprednisolone }\end{array}$ & IO & $\begin{array}{l}0.19 \mathrm{mg}, \\
1.88 \mathrm{mg}, \\
3.75 \mathrm{mg}, \\
7.5 \mathrm{mg}, \\
15 \mathrm{mg}\end{array}$ \\
\hline $\begin{array}{l}\text { Koreckij, } \\
2016\end{array}$ & $\begin{array}{l}\text { Retrospective } \\
\text { case control }\end{array}$ & 44 & $2-4$ & $44(100)$ & $\begin{array}{l}\text { Cervical } \\
\text { radiculopathy, } \\
\text { myelopathy }\end{array}$ & $\begin{array}{l}\text { POD 1, } \\
\text { 6wk, 3mo }\end{array}$ & 22 & $57.6+/-9.9$ & 50 & $\begin{array}{l}\text { IV } \\
\text { dexamethasone } \\
\text { 10mg }\end{array}$ & 22 & $55.1+/-7.9$ & 54.5 & $\begin{array}{l}\text { IV dexamethasone } \\
\text { 10mg + RP } \\
\text { methylprednisolone }\end{array}$ & IO & $15 \mathrm{mg}$ \\
\hline
\end{tabular}

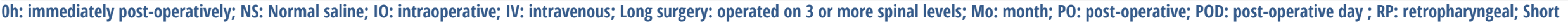
surgery: operated on <3 spinal levels; Wk: week. *Dose equivalents relative to dexamethasone. 
Study quality and risk of bias

The risk of bias for the two retrospective casecontrol studies was assessed using the NewcastleOttawa scale. ${ }^{24}$ One study received 4 out of $9 \mathrm{stars}^{18}$; with 2 stars for study selection, 0 stars for group comparability, and 2 stars for exposure. The other study received 6 out of $9 \mathrm{stars}^{17}$; with 2 stars for study selection, 2 stars for group comparability, and 2 stars for exposure.

\section{Systemic Steroids and Dysphagia/Odynophagia Incidence}

Of the systemic steroid studies, only one study evaluated the incidence of dysphagia in 236 patients who underwent single and multilevel anterior cervical spine procedures. ${ }^{14}$ Patients were given 3 doses of IV methylprednisolone immediately post-op, at $12 \mathrm{~h}$, and at $24 \mathrm{~h}$. Incidence of dysphagia or odynophagia was assessed via patient report at $24-36 \mathrm{~h}$ post-op. 56 out of 78 patients $(71.79 \%)$ who were given steroids experienced dysphagia/odynophagia, compared to 130 patients out of 158 (82.28\%) in the control group.

\section{Severity}

Severity of dysphagia and/or odynophagia was assessed in 3 studies using standardized scoring systems (Table 1) across 214 patients; 116 patients receiving steroids and the remaining 98 receiving normal saline. ${ }^{12,1,15}$ Dysphagia severity was assessed using three different scoring systems: 1) A 10-point visual analogue scale (VAS), in which patients ranked their swallowing difficulty from 0 (no difficulty swallowing) to 10 (worst difficulty swallowing); 2) The Bazaz scale (Table 3); and 3) functional outcome swallowing scale (FOSS) (Table 4). Two studies assessed severity in the acute post-operative setting (i.e. within 1 month post-op) in 102 patients, with 42 control subjects. ${ }^{12,13}$ Nam et al assessed dysphagia severity in 62 consecutive patients undergoing single level ACDF using the VAS. ${ }^{13}$ The patients were randomly assigned into 3 groups (high dose IV dexamethasone $(n=20)$, low dose IV dexamethasone $(n=20)$, normal saline $(\mathrm{n}=22))$. Doses of steroid or saline were given immediately post-op, at $24 \mathrm{~h}$ and $48 \mathrm{~h}$ post-op. $\mathrm{Pa}-$ tients were monitored post-op days 0-5. The mean VAS scores among the 3 groups peaked post-op day 1 and decreased through day 5 ; there was no statistical significance between the groups at any point in the follow-up period. Song et al assessed dysphagia severity in 40 patients undergoing multilevel ACDF with the Bazaz scale. ${ }^{12}$ Twenty patients were given IV methylprednisolone immediately post-op and every $6 \mathrm{~h}$ for the first $24 \mathrm{~h}$ post-op, and the remaining 20 were not given anything. Patients were evaluated daily until discharge. Dysphagia was most severe POD1, with $95 \%$ and $100 \%$ scoring dysphagia as "severe" for steroids and control groups respectively. As dysphagia severity decreased in the two groups, a statistically significant difference was noted through post-op days 2 and 5 . On post-op day 2, $0 \%$ patients in the steroid group ranked their dysphagia as severe compared to $70 \%$ in the control group $(\mathrm{p}=.027)$. On post-op day $5,0 \%$ patients receiving steroids ranked their dysphagia as severe, $15 \%$ as moderate, and $70 \%$ as mild, compared to $70 \%$ moderate and $30 \%$ mild in the control group $(\mathrm{p}=.005)$.

Long-term severity of dysphagia was assessed in one study $^{15}$ in 112 patients after multilevel anterior cervical spine surgery. Patients were randomly assigned into 2 groups, with 56 patients receiving IV dexamethasone and 56 patients receiving saline intraoperatively, and every $6 \mathrm{~h}$ post-op for the first $24 \mathrm{~h}$

\begin{tabular}{|c|c|c|}
\hline Severity & $\begin{array}{r}\text { Problems swallowing } \\
\text { liquids }\end{array}$ & Problems swallowing solids \\
\hline None & None & None \\
\hline Mild & None & Rare \\
\hline Moderate & None/rare & $\begin{array}{r}\text { Occasionally (only with specific } \\
\text { foods) }\end{array}$ \\
\hline Severe & None/rare & Frequent (majority of food) \\
\hline
\end{tabular}

Table 4. Functional Outcome Swallowing Scale (FOSS) for dysphagia severity.

\begin{tabular}{|l|r|}
\hline Score & Symptoms \\
\hline 0 & Normal function; asymptomatic \\
\hline 1 & Normal function; episodic or daily symptoms of dysphagia \\
\hline 2 & $\begin{array}{r}\text { Compensated abnormal function manifested by significant dietary } \\
\text { modifications or prolonged mealtimes w/o weight loss or aspiration }\end{array}$ \\
\hline 3 & $\begin{array}{r}\text { Decompensated abnormal function; daily coughing, gagging, aspira- } \\
\text { tion during meals }\end{array}$ \\
\hline 4 & $\begin{array}{r}\text { Severely decompensated abnormal function; severe aspiration \& bron- } \\
\text { chopulmonary complications; non-oral feeding for most nutrition }\end{array}$ \\
\hline 5 & Non-oral feeding for all nutrition \\
\hline
\end{tabular}


post-op. Dysphagia severity was determined using the functional outcome swallowing scale (FOSS, Table 4 ) at $1 \mathrm{mo}, 3 \mathrm{mo}, 6 \mathrm{mo}, 12 \mathrm{mo}$, and $24 \mathrm{mo}$ postop. Decreased dysphagia severity, as represented by lower FOSS scores, were reported in the steroid group at 1 month post-op (steroid: .064, control: .66, $\mathrm{p}=.027)$; however this difference subsided thereafter.

\section{Prevertebral Soft Tissue Swelling}

Prevertebral soft tissue swelling (PSTS) was evaluated in 2 studies and used as a surrogate for dysphagia. ${ }^{12,13}$ Nam et al assessed PSTS by measuring the area $\left(\mathrm{cm}^{2}\right)$ from the lower border of $\mathrm{C} 1$ to the upper end plate of $\mathrm{C} 7$ for patients receiving high dose dexamethasone, low dose dexamethasone and placebo respectively. ${ }^{13}$ PSTS peaked post-op day 3 and continued to decrease through day 5 but no statistical significance was noted between the groups.

Song et al found similar trends by measuring PSTS length (mm) at each level from C2 to C7 using lateral radiographs. ${ }^{12}$ During post-operative days 2-6, PSTS increased significantly more in the control group than in those receiving steroids $(\mathrm{p}<.001)$.

\section{Time to Fusion}

Fusion status was evaluated using cervical CT scans in one study, with fusion reported when bridging osseous trabeculae were seen spanning each operative level without intervening radiographic lucencies. ${ }^{15}$ At 6 months post-op 39.5\% of patients in the steroid group demonstrated fusion, compared to $60 \%$ in the control group $(\mathrm{p}=.048)$. This difference was not detected at 12 months and 24 months (Fusion rate at 12 months for steroid: $75 \%$, control: $80 \%, \mathrm{p}=.57 ; 24$ months steroid: $92.69 \%$, control: $95.2 \%, \mathrm{p}=.57$ ).

\section{Length of Hospital Stay}

The average hospital stay was shorter in the systemic steroid-receiving group compared to the control group across two separate studies (Song et al: $5.1 \pm .7$ days for the steroid group vs. $6.0 \pm 1.02$ for the control group, $\mathrm{p}=.003)$. $^{12,15}$

Neck Disability

Neck disability after anterior cervical spine surgery was evaluated in one study using the Owestry Dis- ability Index (ODI). ${ }^{15}$ There was no statistically significant difference in neck disability between the two groups at any point post-operatively.

\section{Complications}

Complications across the studies included in this cohort were: vocal cord motility disorders $(\mathrm{n}=8)$; and tonsillar laceration secondary to intubation $(\mathrm{n}=1)$. There were no reports of intraoperative esophageal perforation, vascular compromise, or CSF leak. The complication rate was $2 \%$ ( 9 out of 450 patients).

\section{Local Steroids and Dysphagia/Odynophagia} Incidence

Of the local steroid studies, incidence was reported in two studies. ${ }^{17,18}$ In the first, a large retrospective study, cumulative incidence of dysphagia/odynophagia was $9.5 \%$ ( 23,446 out of 245,754 patients). The incidence in the steroid cohort was $7.88 \%$ (162 out of $2,092)$ compared to $9.52 \%(23,284$ out of 243,662$)$ in the control group. There was statistically significant reduction in incidence of dysphagia in the steroid group ( 29 out of $322,9 \%$ ) in comparison to the control group $(6,633$ out of $45,432,14.6 \%)$ in patients who received multilevel ( 3 or more levels) ACDF ( $p$ $=.005) \cdot{ }^{18}$ The second study evaluated dysphagia using the EAT-10 scale (Table 1) in 44 patients. ${ }^{17}$ Their investigation found no statistically significant difference at 6 weeks post-op; however, by 3 months there was a significant decrease in the dysphagia incidence in the steroid group compared to the control group $(18.2 \%$ vs. $57.1 \%$ respectively; $\mathrm{p}=.012){ }^{17}$

\section{Severity}

Severity of dysphagia and/or odynophagia was assessed in 2 studies using standardized scoring systems (Table 1) across 94 patients; 47 patients receiving steroids and the remaining 47 serving as controls. ${ }^{1,26}$ Lee et al. measured the resolution of odynophagia in the acute post-operative period using the VAS score and found that immediate postoperative mean VAS scores in the steroid and control groups were 2.5 and 5.3 respectively $(\mathrm{p}<.001){ }^{26}$ This difference persisted through 2-week evaluation (mean VAS scores 1.2 and 3.5 for the steroid and control groups, respectively $(\mathrm{p}<.001)$. Koreckij et al utilized the Bazaz scale to evaluate dysphagia in the prolonged post-operative phase, demonstrating that 
$14.3 \%$ of patients receiving steroids had severe dysphagia at 6 weeks compared to $40.9 \%$ in the control group $(\mathrm{p}=.022) .^{17}$

\section{Prevertebral Soft Tissue Swelling}

Two studies measured prevertebral soft tissue swelling (PSTS) at C3-5 using lateral radiographs. ${ }^{16,17}$ Both studies demonstrated decreased PSTS in the patients receiving local steroids immediately postoperatively, however only one study was statistically significant. ${ }^{16}$ In the latter study, ${ }^{16}$ the PSTS difference was maintained at two weeks post-operatively $(\mathrm{p}=.0036)$.

\section{Time to Fusion}

Time to fusion was reported in one study and defined by "the presence of bony extension into the space between the graft in addition to the absence of segmental motion." ${ }^{16}$ The mean follow-up was 21.4 months in the steroid group and 22.3 months in the control group. The steroid group demonstrated union in all patients ( 25 of 25 ), while the control group revealed $96 \%$ fusion (24 of 25 ).

\section{Length of Hospital Stay}

Two studies assessed the length of hospital stay. ${ }^{17,18}$ Patients receiving steroids had shorter length of hospital stays compared to the control groups and reached statistical significance $(1 \pm 1.1$ days, vs. $2 \pm 2.2$ days respectively, $\mathrm{p}<.001$ and $1.27 \pm .6$ vs. $2.2 \pm 1.9$, respectively, $\mathrm{p}=.03$ ).

\section{Neck Disability}

Neck disability after anterior cervical spine surgery was evaluated in two studies. ${ }^{16,17}$ Neither studies demonstrated statistical significance between the two groups at any point during the follow-up periods (Koreckij et al evaluated at 6 weeks and 3 months in and Lee et al at the last follow up, with mean duration of follow-up of 21.4 months and 22.3 months for the steroid and control groups respectively). ${ }^{1,26}$

\section{Esophageal rupture \& other complications}

Across the studies included in this cohort there was one complication reported: wound infection leading to pseudoarthrosis $(n=1)$. There were no reports of intraoperative esophageal perforation, vascular compromise, or CSF leak. The complication rate for this cohort (when reported) was 1.1\% (1 out of 94 patients).

\section{Discussion}

\section{Dysphagia/Odynophagia \& Prevertebral Soft Tissue Swelling}

The purpose of this review was to evaluate the efficacy of perioperative steroids in reducing postoperative dysphagia after anterior cervical spinal surgery by performing a systematic review of the literature.

Dysphagia incidence was uniformly lower with steroids, however statistical significance was inconsistent. It appears that the effect on lowering dysphagia incidence is more pronounced as time passes. This was demonstrated by the statistically significant reduced incidence at 3 months compared to 6 weeks in the Koreckij et al study. ${ }^{17}$ Of note, the effect of intraoperative steroids on the reduction of dysphagia incidence seemed to be more pronounced in procedures involving 3 or more levels. ${ }^{18}$

With the exception of Nam et al, all of the studies demonstrated statistically significant reduced dysphagia severity in the steroid group in comparison to the control group at some point during the follow-up period. ${ }^{12,15-17}$ These results were mirrored by prevertebral soft tissue swelling, suggesting that perioperative steroids also decrease severity of prevertebral soft tissue swelling and associated complications. The effect of steroids on reduction of both dysphagia severity and prevertebral soft tissue swelling was more pronounced in the early post-operative period $(<=2$ weeks) with the effects on dysphagia severity persisting up to 3 months post-op. Despite the apparent association, the role of prevertebral soft tissue swelling in causing dysphagia remains unclear. ${ }^{27-29}$ It should be noted that Nam et al was the only study that consisted of all single level cervical procedures, suggesting that there is more benefit of steroid intervention with multilevel procedures.

Taken together these results provide evidence that perioperative steroids effectively reduce dysphagia and/or odynophagia in the early post-operative period, the benefit being more pronounced in multilevel 
procedures. Perioperative steroids should probably be used in conjunction with other methods for multilevel procedures, such as limiting retraction time ${ }^{30,31}$ and cuff pressure, ${ }^{10}$ with the hope of achieving even greater reduction in post-operative dysphagia.

\section{Systemic vs. Local Steroids}

There were no apparent differences between local and systemic steroids in regards to infections, other complications, and hospital readmission. Intraoperative dose of local steroids can only be administered once, whereas multiple doses of systemic steroids were administered up to $48 \mathrm{~h}$ post-op. The studies that utilized local steroids consistently reported statistically significant differences in dysphagia incidence and severity through 3 months post-op, however the results were more inconsistent in the systemic steroid studies. Taken together these results suggest that local steroids are more cost-effective, and possibly more efficacious in dysphagia/ odynophagia prevention.

\section{Delayed fusion/infection/other complications}

Though delayed fusion has been expressed as a concern for the use of intraoperative steroids, ${ }^{15,30}$ the studies in this review demonstrate that steroids do not significantly hinder fusion rates. Use of perioperative steroids decreased the early fusion rate in the study by Jeyamohan et al, however this drawback did not persist past at 6 months. ${ }^{15}$ This finding was further supported by Lee et al (2011), in which $100 \%$ of patients in the steroid group achieved fusion by the last follow-up. ${ }^{26}$ Despite the reported increased infection rate associated with steroid use in general, ${ }^{19}$ infection rates did not significantly vary among the steroid and control groups in any of the studies. Moreover, a higher number of non-dysphagia/ odynophagia complications were reported in the groups that did not receive steroids. Lee et al (2015) describes esophageal perforation as a potential complication of local perioperative steroids in the late post-operative period, ${ }^{32}$ however this complication was not reported in any of the studies of this review. Given that the study only reports two patient cases, it is difficult to ascertain whether the esophageal perforation was directly related to steroid use. Therefore, it can be concluded that there is no current evidence of an increased complication rate associated with perioperative steroids in anterior cervical spine surgery. Despite this conclusion, the use of steroids is still considered off-label, effective doses are still unknown, and given the theoretical concerns particularly with local administration, caution should be exercised when selecting patients for this intervention.

\section{Limitations \& Future Directions}

This review is limited by the different methods used to report dysphagia and/or odynophagia. These methods included the Bazaz scale, ${ }^{12,17}$ FOSS score, and VAS. ${ }^{13,16}$ The same limitation was encountered with pre-vertebral soft tissue swelling. Effective comparison cannot be achieved without a standardized measure of these outcomes. Also, because various steroid types and doses were used in the included studies, exact dose and type of steroid for desired effect on dysphagia remains unclear. Additionally, given that certain complications such as esophageal perforation or infection are relatively uncommon after ACDF, the studies included in this review were likely not adequately powered concerning them; making it difficult to appropriately compare complication rates between the systemic and local steroid groups. Lastly, there was only one randomized control trial that utilized local steroids; therefore more studies were used with lower levels of evidence than with systemic steroids.

This review highlights the need for a standardized tool to evaluate post-operative dysphagia, in order to better understand the incidence, severity, as well as the effect of steroids. Additionally, despite the comparison done in this review, a prospective study comparing local and systemic steroids would provide more sufficient analysis and better indicate which, if either, is more efficacious in preventing postoperative dysphagia following anterior cervical spine surgery.

\section{Conclusion}

The purpose of this systematic review is to evaluate the effect of peri-operative steroids on the incidence and severity of dysphagia following anterior cervical spine surgery by conducting a systematic review of the literature. Peri-operative steroids reduce dyspha- 
gia after anterior cervical spinal procedures in the early post-operative period, without increasing complications or adversely affecting long-term fusion; and are especially beneficial in patients undergoing multilevel procedures.

\section{References}

1. Daniels AH, Riew KD, Ching A, Birchard KR, Kranenburg AJ, Hart RA. Adverse Events Associated With Anterior Cervical Spine Surgery. J Am Acad Orthop Surg. 2008;16(12):729-738.

2. Riley LH, Skolasky RL, Albert TJ, Vaccaro AR, Heller JG. Dysphagia after anterior cervical decompression and fusion: prevalence and risk factors from a longitudinal cohort study. Spine (Phila Pa 1976). 2005;30(22):2564-2569.

http://www.ncbi.nlm.nih.gov/pubmed/16284596. Accessed May 5, 2016.

3. Riley LH, Vaccaro AR, Dettori JR, Hashimoto R. Postoperative dysphagia in anterior cervical spine surgery. Spine (Phila Pa 1976). 2010;35(9 Suppl):S76-S85. doi:10.1097/BRS.0b013e3181d81a96.

4. Bazaz R, Lee MJ, Yoo JU. Incidence of dysphagia after anterior cervical spine surgery: a prospective study. Spine (Phila Pa 1976). 2002;27(22):2453-2458. doi:10.1097/01.BRS.0000031407.52778.4B.

5. Lee MJ, Bazaz R, Furey CG, Yoo J. Risk factors for dysphagia after anterior cervical spine surgery: a two-year prospective cohort study. Spine $J$. 2007;7(2):141-147. doi:10.1016/j.spinee.2006.02.024. 6. Beutler WJ, Sweeney CA, Connolly PJ. Recurrent laryngeal nerve injury with anterior cervical spine surgery risk with laterality of surgical approach. Spine (Phila Pa 1976). 2001;26(12):1337-1342. http://www.ncbi.nlm.nih.gov/pubmed/11426148. Accessed May 5, 2016.

7. Netterville JL, Koriwchak MJ, Winkle M, Courey MS, Ossoff RH. Vocal fold paralysis following the anterior approach to the cervical spine. Ann Otol Rhinol Laryngol. 1996;105(2):85-91.

http://www.ncbi.nlm.nih.gov/pubmed/8659941. Accessed May 5, 2016.

8. Brown JA, Havel P, Ebraheim N, Greenblatt SH, Jackson WT. Cervical stabilization by plate and bone fusion. Spine (Phila Pa 1976). 1988;13(3):236-240.

http://www.ncbi.nlm.nih.gov/pubmed/3388110. Ac- cessed May 5, 2016.

9. Papavero L, Heese O, Klotz-Regener V, Buchalla R, Schröder F, Westphal M. The impact of esophagus retraction on early dysphagia after anterior cervical surgery: does a correlation exist? Spine (Phila Pa 1976). 2007;32(10):1089-1093. doi:10.1097/ 01.brs.0000261627.04944.cf.

10. Ratnaraj J, Todorov A, McHugh T, Cheng MA, Lauryssen C. Effects of decreasing endotracheal tube cuff pressures during neck retraction for anterior cervical spine surgery. J Neurosurg. 2002;97(2 Suppl):176-179. http://www.ncbi.nlm.nih.gov/pubmed/ 12296675. Accessed May 5, 2016.

11. Chin KR, Eiszner JR, Adams SB. Role of plate thickness as a cause of dysphagia after anterior cervical fusion. Spine (Phila Pa 1976).

2007;32(23):2585-2590. doi:10.1097/

BRS.0b013e318158dec8.

12. Song K-J, Lee S-K, Ko J-H, Yoo M-J, Kim D-Y, Lee K-B. The clinical efficacy of short-term steroid treatment in multilevel anterior cervical arthrodesis. Spine J. 2014;14(12):2954-2958. doi:10.1016/ j.spinee.2014.06.005.

13. Nam TW, Lee DH, Shin JK, Goh TS, Lee JS. Effect of intravenous dexamethasone on prevertebral soft tissue swelling after anterior cervical discectomy and fusion. Acta Orthop Belg. 2013;79(2):211-215. http://www.ncbi.nlm.nih.gov/pubmed/23821974. Accessed October 16, 2015.

14. Pedram M, Castagnera L, Carat X, Macouillard G, Vital J-M. Pharyngolaryngeal lesions in patients undergoing cervical spine surgery through the anterior approach: contribution of methylprednisolone.

Eur Spine J. 2003;12(1):84-90. doi:10.1007/ s00586-002-0495-6.

15. Jeyamohan SB, Kenning TJ, Petronis KA, Feustel PJ, Drazin D, DiRisio DJ. Effect of steroid use in anterior cervical discectomy and fusion: a randomized controlled trial. J Neurosurg Spine.

2015;23(2):137-143. doi:10.3171/

2014.12.SPINE14477.

16. Lee S-H, Kim K-T, Suk K-S, Park K-J, Oh K-I. Effect of retropharyngeal steroid on prevertebral soft tissue swelling following anterior cervical discectomy and fusion: a prospective, randomized study. Spine (Phila Pa 1976). 2011;36(26):2286-2292. doi:10.1097/ BRS.0b013e318237e5d0. 
17. Koreckij TD, Davidson AA, Baker KC, Park DK. Retropharyngeal Steroids and Dysphagia Following Multilevel Anterior Cervical Surgery. Spine (Phila Pa 1976). 2016;41(9):E530-E534. doi:10.1097/ BRS.0000000000001293.

18. Cancienne JM, Werner BC, Loeb AE, et al. The Effect of Local Intraoperative Steroid Administration on the Rate of Post-Operative Dysphagia Following ACDF: A Study of 245,754 Patients. Spine (Phila Pa 1976). December 2015. doi:10.1097/

BRS.0000000000001407.

19. Scanzello CR, Figgie MP, Nestor BJ, Goodman SM. Perioperative management of medications used in the treatment of rheumatoid arthritis. HSS J. 2006;2(2):141-147. doi:10.1007/s11420-006-9012-5. 20. Moher D, Liberati A, Tetzlaff J, Altman DG. Preferred reporting items for systematic reviews and meta-analyses: the PRISMA statement. PLoS Med. 2009;6(7):e1000097. doi:10.1371/journal.pmed.1000097.

21. Meikle AW, Tyler FH. Potency and duration of action of glucocorticoids. Effects of hydrocortisone, prednisone and dexamethasone on human pituitaryadrenal function. Am J Med. 1977;63(2):200-207. 22. Webb, R., Singer M. Oxford Handbook of Critical Care. Oxford; New York: Oxford University Press; 2005.

23. Dixon J. Second-line agents in the treatment of rheumatic diseases. Inf Heal Care. 1991;(456).

24. Wells G, Shea B, O'Connell D, et al. The Newcastle-Ottawa Scale (NOS) for assessing the quality if nonrandomized studies in meta-analyses. (Available from URL http//wwww.ohri.ca/programs/clinical_epidemiology/oxford.asp). 2012:2012.

doi:10.2307/632432.

25. Wright JG, Swiontkowski MF, Heckman JD. Introducing levels of evidence to the journal. J Bone Joint Surg Am. 2003;85-A(1):1-3. doi:10.1097/ BOT.0b013e318247c931.

26. Lee S-H, Kim K-T, Suk K-S, Park K-J, Oh K-I. Effect of retropharyngeal steroid on prevertebral soft tissue swelling following anterior cervical discectomy and fusion: a prospective, randomized study. Spine (Phila Pa 1976). 2011;36(26):2286-2292. doi:10.1097/ BRS.0b013e318237e5d0.

27. Kepler CK, Rihn JA, Bennett JD, et al. Dysphagia and soft-tissue swelling after anterior cervical surgery: a radiographic analysis. Spine $J$.

2012;12(8):639-644. doi:10.1016/

j.spinee.2012.03.024.

28. Khaki F, Zusman NL, Nemecek AN, Ching AC, Hart RA, Yoo JU. Postoperative prevertebral soft tissue swelling does not affect the development of chronic dysphagia following anterior cervical spine surgery. Spine (Phila Pa 1976).

2013;38(9):E528-E532. doi:10.1097/

BRS.0b013e31828a2992.

29. Stachniak JB, Diebner JD, Brunk ES, Speed

SM. Analysis of prevertebral soft-tissue swelling and dysphagia in multilevel anterior cervical discectomy and fusion with recombinant human bone morphogenetic protein-2 in patients at risk for pseudarthrosis. J Neurosurg Spine. 2011;14(2):244-249. doi:10.3171/2010.9.SPINE09828.

30. Ramos-Zúñiga R, Saldaña-Koppel DA. Letter to the Editor: Reduction of early postoperative dysphagia via steroid use after anterior cervical surgery. $J$ Neurosurg Spine. February 2016:1. doi:10.3171/ 2015.9.SPINE151162.

31. Ramos-Zúñiga R, Díaz-Guzmán LR, Velasquez S, Macías-Ornelas AM, Rodríguez-Vázquez M. A microsurgical anterior cervical approach and the immediate impact of mechanical retractors: A case control study. J Neurosci Rural Pract. 6(3):315-319. doi:10.4103/0976-3147.158748.

32. Lee S-H, Mesfin A, Riew KD. Delayed esophageal perforation after anterior cervical fusion and retropharyngeal steroid use: a report of two cases. Spine J. 2015;15(10):e75-e80. doi:10.1016/ j.spinee.2015.06.058.

\section{Disclosures \& COI}

None of the authors have any disclosures or conflicts-of-interests to report with respect to this manuscript.

\section{Corresponding Author}

Faiz U. Ahmad, MD, MCh, Department of Neurological Surgery, Emory Faculty Office Building, 49 Jesse Hill Drive SE, Room 341*, Atlanta, GA 30303. faiz.ahmad@emory.edu.

Published 6 March 2017. 
This manuscript is generously published free of charge by ISASS, the International Society for the Advancement of Spine Surgery. Copyright ๑ 2017
ISASS. To see more or order reprints or permissions, see http://ijssurgery.com. 